Zhu, Lihong, and Debra F. Spidal. "Shared Integrated Library System Migration From a Technical Services

Perspective." Technical Services Quarterly 32, no. 3 (July 2015): 253-273.

Submitted by

Anna Appleman, Copy Cataloger

John Bulow Campbell Library, Columbia Theological Seminary

\title{
TESTIMONY
}

\section{Creating MARC and MODS 3.5 Records for Burke's Syriac Manuscript Collection}

I started working at the Burke Library (Burke) at Union Theological Seminary (one of the Columbia University Libraries) in 2011 as the Collections Assistant. Three months prior I had finished my M.A. in Biblical Studies at the same seminary and was thrilled to continue spending time with materials that had become so dear to me. During my first week of work my supervisor, Matthew Baker, took me on a tour of our rare book storage, the maintenance of which would occupy a large portion of my work. He showed me our Syriac manuscript collection and told me that they were minimally cataloged. The only entry in our online catalog for them was a short collection-level placeholder that had almost no information about the manuscripts either as a whole or individually. This was largely because Syriac is a fairly obscure, ancient language that is now generally only used in liturgical contexts and transliteration is challenging. I briefly mentioned that I had taken Syriac at the seminary and would be interested in working with them if at all possible. Four years later I was able to catalog all 48 manuscripts as part of a capstone project for my library science degree. The project entailed the creation of MARC and MODS 3.5 records for each manuscript, with a focus on exploring and utilizing various software programs and cataloging standards. During various parts of the project I worked extensively with Matthew Haugen, a Rare Book Cataloger at Columbia University Libraries (CUL), and Melanie Wacker, the Metadata Coordinator for CUL. By the time the project started I had completed coursework in cataloging and metadata and was also doing some copy cataloging.

The brief record for these manuscripts was a collection record with the title Syriac Manuscripts Collection, an approximate date range of 11th c.-20th c. and a call number of UTS. Ms. Syr. 1-48. My goal was to create individual MARC records for each manuscript. I used RDA guidelines for the descriptive content and Library of Congress Subject Headings and the Getty Art \& Architecture Thesaurus for subject and genre terms. I also wanted to work with metadata transformation since I was submitting the project to Queens College as part of my library science program. I was aware that MODS is quickly becoming a common and useful schema for library cataloging and wanted to use something that would be relevant for CUL sometime in the future. I used CUL's implementation of MODS 3.5 (the most recent version available at the time). In addition, I created transliterated fields for any information in Syriac using the ALA-LC transliteration table.

\section{Workflow}

Since this project was beyond the scope of my regular duties, the work was completed on a volunteer basis outside my normal working hours. The director of the Burke Library, Beth Bidlack, and my direct supervisor, Matthew Baker, were instrumental in getting the necessary permissions for me to complete the project. In addition, Matthew Haugen proofread every record for consistency and accuracy to ensure that they met CUL's standards for cataloging. The project totaled 72 hours and yielded $48 \mathrm{MARC}$ records and 48 MODS records.

The workflow started with Matthew Haugen creating an RDA record template in OCLC. It included the 336, 337 and 338 fields for content, media, and carrier and a 524 field to record the preferred citation for each manuscript. I entered all of the information for each manuscript and saved each record in our local save file. This included deciding on a title, searching for authorized name headings, selecting subject headings from the Library of Congress authority file, selecting an appropriate genre from the Getty Art \& Architecture Thesaurus and adding any other relevant details. I consulted the file folders that accompany each manuscript for provenance information, along with several published works about the collection (Syriac manuscripts, 1977; Clemons, 1965; Goshen-Gottstein, 1979). In addition, if I 
found an author or other contributor that did not have an established heading in the Name Authority File (NAF), I submitted a preferred form of the name to Matthew who then did further research and established the heading for me. I also transliterated any fields containing Syriac script. Syriac vocalization is quite complicated and I am still reviewing the transliterated fields for ALA-LC compliance. Matthew reviewed each record in the OCLC save file before adding them to WorldCat. He then exported the records into CUL's catalog and created holding and item records.

Once the MARC records were complete, I downloaded them onto my workstation and used the Oxygen XML Editor to convert them into MODS 3.5 records. I consulted with Melanie Wacker about this process, in particular about fields that were specific to CUL's implementation of MODS. Lastly, copies of the MODS records were saved on the shared network drive for future use.

\section{Titles}

If a manuscript had either a title page or colophon, I used that for the title in Syriac script and devised titles when necessary. I added uniform titles whenever possible, largely for biblical and liturgical works. Ultimately, fifteen of the 48 manuscript records have titles recorded in Syriac script. I added transliterated fields for the transcribed titles in Syriac and also supplied alternate English titles as additional access points. When the manuscripts were either too fragmentary or missing too many pages to derive a Syriac title, I devised one using either Moshe H. GoshenGottstein's Syriac Manuscripts in the Harvard College Library or the information available in files compiled about each manuscript. When I derived titles from Goshen-Gottstein, I either removed the word Nestorian or replaced it with madnhaya when it was used to refer to the font. I made this decision because the term Nestorian, while common in Syriac studies, is both inaccurate and often offensive. It has its origins in an early controversy in the Syriac church concerning the nature of Christ (Müller and Hage, 2015) and is too derisive to be included. The term madnhaya simply means eastern and is not only used internally by the group that has been labeled Nestorian, but is also used as a term for the Syriac script. Since the bulk of these manuscripts are written in the madnhaya script, the decision to use this term instead of the more common Nestorian is significant. In each case, I recorded the source of the title in the record in a 500 note so that both patrons and future librarians would know where the titles came from.

\section{Controlled headings}

The use of controlled author and uniform title headings proved extremely difficult for this project. While I found authority records in the NAF for several authors/creators, it often took several hours to locate them. For example, manuscript 19 includes two works by three authors: Rabban Hunayn, Rabban Hananisho, and Abd-Isho of Gazarta. Finding the controlled form of these names proved to be a challenge. Matthew Haugen and I scoured Wikipedia pages and confirmed authors' identities based on my general knowledge of the period. I was able to connect AbdIsho of Gazarta to the controlled form Abdīshō' IV, Chaldean Patriarch of Babylon, -1570 because a note in the authority record referenced the Wikipedia article for Abdisho IV Maron. I found mention of him being from Gazarta in that article (Abdisho IV Maron, 2014) which connected the heading to the author of the manuscript. Likewise, the controlled form for Rabban Hananisho is 'Anân-Îshô', active 7th century. 'Anân-Îshô' is actually an incorrect or outdated transliteration for the Syriac; the name starts with a character that is currently transliterated with the letter h. Searches using current transliteration standards yielded no results. None of the controlled forms have references in the Syriac script, making it very challenging to locate them in the authority file. NACO currently does not allow the addition of Syriac script in authority records, which means that any searches must rely on transliterated terms (Library of Congress, 2008). I understand that this is not an uncommon problem when cataloging foreign language manuscripts and it was definitely a positive learning experience for me.

Mathew, Melanie, and I discussed whether or not to use the term "manuscripts" as a subject term (MARC field 650) or as a genre term (MARC field 655) and decided to use the 655 field for genre terms from the Getty Art \& Architecture Thesaurus as well as the 650 field for the Library of Congress Subject Heading Manuscripts, Syriac. This allows patrons to search using either the subject or genre/form index. Since few patrons utilize the genre search effectively, I felt it was necessary and helpful to provide alternate access via a subject heading even if it is somewhat technically incorrect. 


\section{Classification}

The call numbers assigned to the collection over the years have varied somewhat and I noted these variations in the records where they may impact access. Often these changes were found in the file folders associated with the items as well as in the Goshen-Gottstein print catalog. I retained the numbers assigned by Goshen-Gottstein as classification numbers since they are consistently used for researcher requests and citations. It is a simple classification system that numbers the manuscripts from 1 to 48, based primarily on the order in which they were acquired. Additionally, each call number includes the prefix UTS Ms. Syr. Prefixes like this have been used in other manuscript collections at Burke and so it kept the classification in line with that practice.

\section{MARC and MODS}

The conversion from MARC records to MODs records was relatively easy once the steps were ironed out. While CUL's OPAC offers a direct MARCXML download option, this did not provide the correct namespace prefixes and made reliable conversion to MODS extremely difficult. So, after downloading MARC records from the local catalog, I used MARCEdit to convert the MARC files to MARCXML files. I explored using MARCEdit to convert them directly from MARC to MODS but discovered that the version of MARCEdit that I had would only generate MODS 3.0 records. The Library of Congress had recently released version 3.5 which offers a much richer level of description so I converted the MARCXML files to MODS 3.5 using Oxygen. Oxygen is an XML editor and validator that I found extremely user-friendly. It is not free but does not (as far as I can tell) require special software or platforms in order to run.

I edited and validated all 48 records at once in Oxygen using a transformation scenario. The files were edited to incorporate local standards as well as holdings information, including <location> and <shelfLocation> tags. This holdings information was not included in the MARC records that I downloaded from CUL's OPAC since the OPAC only offers the option to download the bibliographic record; holdings are created separately and linked to the bibliographic record. Because the 650 MARC tag did not correctly map onto the MODS < physicalDescription> tag, I edited the records to include the heading Manuscripts, Syriac in the form tag. Finally, during the conversion between MARC and MODS the MARC 710 field, which was used for the name of the collection, was converted to a generic $<$ name type="corporate" $>$, instead of a <relatedItem $>$ tag, which is the convention preferred at CUL.

For a full comparison between the MARC and MODS records that includes Syriac script see:

https://clio.columbia.edu/catalog/11363619/librarian_view

and

http://elizabethmiraglia.weebly.com/uploads/4/6/0/9/46097377/syr19-mods3-5.xml

The rest of the MARC records can be viewed at library.columbia.edu by searching for "Syriac Manuscripts Collection (Burke Library, Union Theological Seminary).”

Once I validated the records, I saved them to a shared drive where they will be accessible for use in future nonMARC cataloging projects. The library staff hope to eventually secure funding to digitize some or all of the manuscripts and this metadata will prove useful when the time comes.

\section{Conclusion}

Creating MARC and MODS records for these manuscripts was by far the most challenging project I had during my entire MLS program. I found myself constantly questioning my skills, both in cataloging and in Syriac. I realized how much I loved tracking down each obscure reference to an author so that the forms of his name could be recorded in the authority record as they appeared on the item. I loved feeling like I was truly and actively contributing something to an international database. I also realized how limiting current subject headings are for items like these manuscripts. In many cases I found myself wanting to add Syriac terms as subject headings but was unable to do so. I almost always found acceptable headings in English but the value that would be added by being able to search in Syriac for terms such as the " "ז, م", (yhídyā) "only-begottenness" of Jesus is not available and it is not an easily translated concept. I am hopeful that as libraries learn how to embrace and utilize the linked data environment, there will be more flexibility in this area and that we will be able to add vernacular search terms to records. 
Transliteration was one of the most difficult parts of the whole project. In fact, I am still revising the transliterations that I created since I have been able to find better tools to assist with the vocalization. Part of the difficulty stems from the fact that I personally dislike using transliteration; I find it to be a frustrating and finicky bridge that I almost never use correctly in my own searching. It is usually easier to either search in the native script (if available) or to use subject/genre headings to find what I need. Transliteration was also especially difficult with these manuscripts since the vocalization on the items is inconsistent and generally had to be supplied.

This project taught me more about cataloging rare manuscripts than I had hoped I would learn. It also taught me where the gaps in my knowledge are and what resources are available to fill them. I cannot express enough my gratitude to everyone at CUL who helped me: especially Matthew Haugen, Melanie Wacker, Matthew Baker, and Beth Bidlack for their constant advice and encouragement.

\title{
Resources
}

Abdisho IV Maron. (2014). Retrieved from http://en.wikipedia.org/wiki/Abdisho_IV Maron

Clemons, J. (1965). A checklist of Syriac manuscripts in the United States and Canada. Orientalia Christiana Periodica, 31(1), 214-229 and 478-517.

Goshen-Gottstein, M. (1979). Syriac manuscripts in the Harvard College library: a catalogue. Missoula, Mont.: Scholars Press.

Müller, C. \& Hage, W. (2015). Nestorians. In Encyclopedia of Christianity Online. Retrieved from http:// referenceworks.brillonline.com/entries/encyclopedia-of-christianity/nestorians-N120

Library of Congress. (2008). Non-latin script data in name authority records: frequently asked questions. Retrieved from http://www.loc.gov/catdir/cpso/nonlatinfaq.html

Syriac manuscripts in the Union Theological Seminary Library : a compilation of relevant literature. (1977).

\author{
Submitted by \\ Elizabeth Miraglia, Serials Specialist \\ Geisel Library, UC San Diego*
}

*All of the work for this project was completed outside of my affiliation with UC San Diego and is not considered endorsed by the university. 